\title{
Oswoić historię. Namysł nad rolą kabały w twórczości Czesława Miłosza na przykładzie tomu Dalsze okolice
}

Krzysztof Brenskott

TEKSTY DRUGIE 2018, NR 5, S. 65-87

DOI: 10.18318/td.2018.5.4

Dodczas lektury prac badawczych poświęconych elementom rozmaitych tradycji filozoficzno-religijnych występującym w twórczości Czesława Miłosza zwraca uwagę stosunkowo niewielka ilość tekstów poświęconych kabale. Literatura przedmiotu dotycząca tej tradycji wypada dość skromnie na tle literatury analizującej wątki choćby buddyjskie, chrześcijańskie czy gnostyckie. Refleksja nad motywami kabalistycznymi, jeżeli już się u badaczy pojawia, to najczęściej przy okazji omawiania

1 O wadze motywów gnostyckich w twórczości Miłosza oraz o sile tego kierunku badawczego świadczy fakt, że w wydanym w 2016 roku tomie Miłosz. Dyskursy znajdują się aż trzy artykułu poświęcone tylko tej tradycji. Patrz: K. Brenskott Dyskurs krytyczny o dyskursie opisującym gnostycyzm w twórczości Czesława Miłosza, S. Ciupka Elementy gnostyckiego, manichejskiego myślenia w twórczości Czesława Miłosza i K. Fedorowicz Poezja jako gest przezwyciężenia gnozy? Rozważania na marginesach „Ziemi Ulro” Czesława Miłosza, w: Miłosz. Dyskursy, red. M. Bernacki, A. Matuszek, Wydawnictwo Naukowe Akademii Techniczno-Humanistycznej w Bielsku-Białej, Bielsko-Biata 2016.
Krzysztof Brenskott

- mgr, autor tekstów:

Bóg złego Prawa.

Próba gnostyckiej

interpretacji Procesu

Franza Kafki („Konteksty Kultury"), Dyskurs

krytyczny o dys-

kursie opisującym

gnostycyzm w dziele

Czesława Miłosza

(w tomie Miłosz.

Dyskursy), Cyberlu-

dowy jarmark, czyli

wgraa Leszka Onaka

i Łukasza Podgórniego.

Rzecz o krakowskiej

poezji cybernetycznej

( w tomie Zemsta ręki

śmiertelnej. Interpre-

tacje wierszy poetów

XXiXXI wieku). 
przez nich związków Miłosza z judaizmem (co wydaje się oczywiste) i przywoływanym już gnostycyzmem, którego nieoczywiste związki z myślą kabalistyczną, wydaje się dość istotne przy próbie udzielenia odpowiedzi na pytanie o to, jaką rolę mogła odgrywać kabała w twórczości polskiego noblisty i jakie elementy tej twórczości oraz jakie pojawiające się w niej motywy mogą uruchamiać kabalistyczną interpretację.

Jeżeli jednak chce się pisać o związkach gnostycyzmu z twórczością Miłosza, to trzeba najpierw określić czym ten gnostycyzm miałby być - zarówno dla poety, jak i dla badacza² tej twórczości:

Opisując motywy gnostyckie w twórczości Miłosza, trzeba zaznaczyć, że nie opisuje się tego, na ile twórczość pisarza odpowiada odnalezionym pismom z Nag Hammadi, a raczej na ile w poezji poety pojawiają się nawiązania do "gnostycyzmu", rozumianego jako pewien konstrukt stworzony przez m.in.: Jonasa czy Ojców Kościoła [...] Nie sugeruje się więc, że twórczość Miłosza rekonstruuje idee z odnalezionych pism gnostyków, ale jedynie wyobrażenie o "gnostycyzmie",które funkcjonuje w kulturze. ${ }^{3}$

Na dzieła Jonasa i jego interpretację gnostycyzmu Miłosz powoływał się w Ziemi Ulro ${ }^{4}$. Można tam również znaleźć źródła wyobrażeń polskiego noblisty o kabale:

Słowo „Kabała” obrosło w mnóstwo skojarzeń ujemnych i jest prawie równoznaczne z magią, chiromancją, zaklęciami, wywoływaniem demonów etc. - czym zresztą była przez stulecia kabalistyka na poziomie ludowym. W rozdziałach o Mickiewiczu powoływałem się na książkę Gershoma Scholema On the Kabbalah and its symbolism. Historyk ten jest

2 Kategoria gnostycyzmu bardzo rzadko bywa problematyzowana w polskim literaturoznawstwie - badacze wykorzystują ją doksalnie i bezrefleksyjnie, powołując się na nieaktualne definicje (np.: definicję z 1966 roku z Messyny) i wykorzystując ustalenia np.: Hansa Jonasa, niczym tego wyboru nie uzasadniając. Zainteresowanych tym zagadnieniem odsyłam do tekstów Fryderyka Kwiatkowskiego (zob. F. Kwiatkowski About the Concept of "Gnosticism" in Fiction Studies, "Comparative Literature and Culture" 2016 nr 18; F. Kwiatkowski A Critical Analysis of the Concept of "Gnosticism" in Polish Literary Studies, "Canadian-American Slavic Studies" 2018 nr 52).

3 K. Brenskott Przekroczyć dualizm. Dialog gnostycyzmu i buddyzmu zen w twórczości Czesława Miłosza na przykładzie Dalszych okolic, "Zagadnienia Rodzajów Literackich” 2018 nr 1, s. 59. 
też autorem innej książki, zatytułowanej po prostu Kabbalah (angielski przekład 1974). ${ }^{5}$

Dalej Miłosz cytuje fragmenty prac Scholema ${ }^{6}$ oraz referuje poglądy Izaaka Lurii „czerpiąc z dzieł Gershoma Scholema”. Pewne są więc dwie rzeczy: po pierwsze, Miłosz czerpał swoją wiedzę o kabale z prac Gerschoma Scholema. Po drugie, noblista przejął od ojca badań nad mistycyzmem żydowskim specyficzną interpretację tradycji kabalistycznej, Jeżeli więc chce się szukać śladów kabały w twórczości poety, to trzeba posługiwać się pracami Scholema, ewentualnie pracami jego kontynuatorów - autor niniejszej pracy odradza więc porównywanie wątków z poezji Miłosza do kabały rozumianej inaczej niż w duchu Scholemowskim ${ }^{8}$.

Krzysztof Kunisz wśród koncepcji religijnych inspirujących Miłosza wymienia - oprócz gnostycyzmu - kabałę ${ }^{9}$ traktując ją jako specyficzną odmianę gnozy:

5 Tamże, s. 211.

6 Tamże.

7 Tamże, s. 217.

8 Zdawać sobie trzeba sprawę z tego, że błędem jest traktowanie dzisiaj dorobku Scholema jako - jak podchodzą do tego niektórzy badacze i jak w przytoczonym wyżej fragmencie Ziemi Ulro pisał Miłosz - próby historycznego, obiektywnego referowania założeń kabały. Choć autor Kabały i jej symboliki uważał się za historyka kabały to jednak, traktował swoją pracę jako filologiczny komentarz do tradycji. Dlatego, referując (podobnie jak Miłosz) założenia kabały Izaaka Lurii, Jakub Górski pisze o „interpretacji kabały luriańskiej Gerschoma Scholema” (J. Górski Teologia negatywna Theodora W. Adorno - wprowadzenie , "Kwartalnik Filozoficzny” 2014 nr 4, s. 42), a Piotr Sawczyński nazywa badacza "nietuzinkowym interpretatorem tradycji” i pisze o "modernistycznej rewizji, jakiej poddaje kabałę Scholem" (P. Sawczyński Dwa wymiary nicości. Gerschom Scholem i paradoksy mistyki żydowskiej, "Logos i Ethos” 2017 nr 46, s. 115-119). Nie wnikając w dalsze szczegóły, istotne dla badaczy twórczości Miłosza jest to, że praca Scholema to "rewizja” i „interpretacja” kabały - polski poeta przejmie więc tę interpretacje wraz z lekturą. Wpływ Scholema na wyobrażenia dotyczące kabały jest tak ogromny, że - przykładowo - Eitan P. Fishbane pisze o post-Scholemowskich badaniach nad kabałą [post-Scholem Kabbalah scholarship] (E. P. Fishbane Jewish Mystical Hermeneutics: On the Work of Moshe Idel, "The Journal of Religion" 2005 nr 1, s. 99), Idel Moshe mówi o szkole Scholemowskiej [Scholemian school] (M. Idel Defining Kabbalah: The Kabbalah of the Divine Names, https://www.academia. edu/8739809/_Defining_Kabbalah_The_Kabbalah_of_the_Divine_Names [28.09.2018]), a Boaz Huss o „apostołach Scholema” [Gerschom Scholem disciples] (B. Huss The Mystification of the Kabbalah and the Modern Construction of Jewish Mysticism, "BGU Review” 2008 No. 33, s. 1).

9 K. Kunisz Tożsamość religijna Czesława Miłosza i jego gnostyckie inspiracje, "Logos i Ethos” 2012 nr 2, s. 126. 
Na kartach Ziemi Ulro Miłosz analizuje swoje wcześniejsze inspiracje i szuka odpowiedzi na pytanie unde malum gdzie indziej. W okresie pisania ZiemiUlro i później bliższy Miłoszowi poglądowo jest gnostycyzm żydowski niż ten o rodowodzie babilońskim. Wpływ na to miała zapewne inspiracja O.W. Miłoszem, Blakiem i Swedenborgiem ${ }^{10}$.

Zarówno dla Oskara Miłosza, jak i Czesława Miłosza główną inspiracją gnostycką musiała być kabała luriańska, czyli nauki Izaaka Lurii z XVI wieku, być może również w interpretacjach z przełomu XVII i XVIII wieku z terenów Prowansji i północnej Hiszpanii."

Pytanie unde malum?, będące w świetle analiz badaczy podstawą występowania gnostycyzmu w dziele Miłosza ${ }^{12}$, uruchamia również - zdaniem Kunisza - wątki i motywy kabalistyczne.

Nie tylko Kunisz stwierdza istnienie silnych relacji między kabałą i gnostycyzmem, występującymi w twórczości polskiego noblisty. W Problematyce żydowskiej w twórczości Czesława Miłosza Marek Bernacki pisze:

Koncepcje manichejsko-gnostyckie Miłosza (w tym np. nieortodoksyjna koncepcja poetyckiej apokatastasis) zbudowane w nawiązaniu do żydowskiej Kabały, szczególnie w wydaniu takich myślicieli żydowskich, jak Izaak Luria czy Gershom Scholem, czego dowodem są rozważania Miłosza poczynione przede wszystkim w Ziemi Ulro. ${ }^{13}$

Zdaniem badacza kabała przynależy do tych samych obszarów myśli Miłosza, współtworząc, wraz z gnostycyzmem i manicheizmem, pewien obraz. Ireneusz Kania dodaje, że zarówno w myśli gnostyckiej, jak i kabalistycznej pociągać będzie Miłosza „potencjał zbawczy wpisany w każdą żywą istotę" połączony z wizją upadku" ${ }^{14}$ Również Łukasz Tischner pisze,

10 Tamże, s. 131.

11 Tamże, s. 132.

12 Takie wnioski pojawiają się w m.in.: Z. Kaźmierczyk Dzieło demiurga. Zapis gnostyckiego doświadczenia egzystencji we wczesnej poezji Czesława Miłosza, słowo/obraz terytoria, Gdańsk 2011.

M. Bernacki Problematyka żydowska w twórczości Czesława Miłosza - rekonesans, „Konteksty Kultury" $2013 \mathrm{nr} 1 / 2$, s. 124.

14 I. Kania Czesław Miłosz a buddyzm, w: Miłosz i Miłosz, red. A. Fiut, A. Grabowski, Ł. Tischner, Księgarnia Akademicka, Kraków 2013, s. 157. 
że „odzyskiwanie boskiego synostwa" jest podobne w gnostyckiej apokatastazie i kabalistycznej koncepcji tikkum ${ }^{15}$. Z kolei według Krisa Van Heuckeloma, tym, co łączy te dwie tradycje w tekstach Miłosza, jest "defektywny charakter świata", który to świat pozostaje we władaniu sił ciemności ${ }^{16}$. Badacz przywołuje też ważny cytat autorstwa samego Miłosza, pochodzący z recenzji nowego, polskiego przekładu pierwszej księgi Tory:

W pewnym jednak momencie historycznym następuje spotkanie platonizmu, gnozy i heterodoksji żydowskiej, dając razem kabalistyczne poszukiwanie odpowiedzi na pytanie, jak to się stało, że Bereszit bara Elohim, że „na początku stworzył Bóg”, jak to nastąpiło i w jaki sposób. Jest to olbrzymie pole dociekań Kabały, a także średniowiecznej chrześcijańskiej scholastyki ${ }^{17}$

Również dla Miłosza kabała wypływa z gnozy, nie jest jednak tak, że tradycje te są według niego ze sobą tożsame, nierozerwalnie splecione. Z powyższego cytatu można wywnioskować, że gnostycyzm jest jednym z dopływów myśli kabalistycznej, podstawą na której wyrosną wyobrażenia teozoficzne i kosmogoniczne. Miłosz wyznacza jednak kabale nieco inne zadanie niż gnozie - ma ona poszukiwać odpowiedzi na pytanie o przyczynę powstania świata, uwzględniając jednocześnie zagadnienie wszechobecności zła. Może być więc traktowana jako sposób złagodzenia "manichejskiego ukąszenia" i próba powrotu na grunt myśli judeochrześcijańskiej, wzbogaconej o pytania stawiane przez gnostycyzm. Innymi słowy: o ile gnostycyzm i manicheizm są dla Miłosza wyrazem negatywnego odbioru rzeczywistości i egzystencji, o tyle kabała jest poszukiwaniem prawdy o stworzeniu, -prawdy opartej na tymże odbiorze rzeczywistości, lecz nie zawężającej się tylko do niego. Co niezwykle istotne badacze kabały nie są zgodni co do słuszności tezy, że rozwój kabały miałby być związany z gnostycyzmem ${ }^{18}$, którą stawiał Scholem (na

15 Ł. Tischner Sekrety manichejskich trucizn: Miłosz wobec zła, Znak, Kraków 2001, s. 27.

16 K. Van Heuckelom „Patrzeć w promień od ziemi odbity”. Wizualność w poezji Czesława Miłosza, Wydawnictwo IBL PAN, Warszawa 2004, s. 197.

Tamże, s. 35 .

18 B. Huss Kabbalah and its Contemporary Revival, "The 8th CISMOR Annual Conference on Jewish Studies", http://www.cismor.jp/uploads-images/sites/2/2018/05/Kabbalah-and-Contemporary-Revival.pdf [29.09.2018]. 
którego wpływ miał przecież Hans Jonas!) - to od niego Miłosz zaczerpnął to wyobrażenie. Gerschom Scholem pisze, że „jest rzeczą pewną, że istnieją nici łączące tradycję kabalistyczną ze zdobyczami gnostycyzmu"' ${ }^{\text {. }}$. Jego zdaniem związki te oscylują wokół pytania unde malum?:

Pytanie „unde malum?”, „skąd pochodzi zło?”, jest dla myśli wczesnych gnostyków chrześcijańskich problemem równie ważnym jak dla żydowskiej myśli średniowiecznej. Dla teozoficznej szkoły kabały, powiązanej przecież z wczesną gnozą nie tylko z racji podobnego psychologicznego nastawienia, lecz również licznymi wątkami historycznymi, pochodzenie i istota zła jest sprawą o prawdziwie kardynalnym znaczeniu. $^{20}$

Podobnie jak dla gnostyków, tak dla kabalistów istnienie zła we wszechświecie stworzonym przez Boga było problemem, którego nie dało się zignorować. Wręcz przeciwnie, zdaniem Scholema

istnienie zła jest dla większości kabalistów - jako autentycznych depozytariuszy mityczności - jednym z najpotężniejszych czynników napędzających ich myśl, która ustawicznie próbowała uporać się z tym problemem. ${ }^{21}$

Stąd - w interpretacji Scholema - pokrewieństwo myśli gnostyckiej i kabalistycznej.W przywołanym wcześniej cytacie autora Kabaty ijej symboliki pojawia się jednak jeszcze jeden rodzaj relacji między tymi dwoma tradycjami: wpływy historyczne. Badacz wykazuje szereg zapożyczeń i paralel wczesnej mistyki żydowskiej - mistyki merkawy (Tronu), będącej prekursorką kabały - i gnostycyzmu, stwierdzając jednak że:

Niezależnie od tego, jak daleko można by posunąć paralele między rozmaitymi koncepcjami gnostyków a mistykami merkawy, ich pojmowanie Boga jest całkowicie odmienne. W tekstach Hechalot Bóg jest przede wszystkim królem [...] Naprawdę bezpośredni wyraz znajdują

G. Scholem Kabała i jej symbolika, przeł. R. Wojnakowski, Aletheia, Warszawa 2014, s. 141. S. 261. 
w religijnym życiu tego kręgu niemal wyłącznie takie atrybuty Boga jak majestat, monarsze dostojeństwo i okazałość. ${ }^{22}$

Mimo występowania pewnych podobieństw wczesna mistyka żydowska nie była systemem dualistycznym, nastawionym wrogo wobec Stwórcy. Obie tradycje spotkają się w księdze Bahir ${ }^{23}$ - dziele wczesnej kabały - a za jej pośrednictwem elementy gnostycyzmu i mistyki Merkawy wywrą "głęboki wpływ na rozwój kabalistycznej teozofii w XIII w."24. Kabała próbująca pogodzić dualistyczne spojrzenie gnozy z chwalebnym wobec Stwórcy nastawieniem mistyki Tronu będzie musiała spróbować przekroczyć dualizm:

Kabaliści nie są dualistami. Jeśli nawet, historycznie rzecz biorąc, ich myśl wykazuje związki z myślą gnostyków (dla których Bóg ukryty i Bóg Stwórca to przeciwieństwa), to przecież cała energia ortodoksyjnej spekulacji kabalistycznej kieruje się na ominięcie tych dualistycznych konsekwencji ${ }^{25}$

Jednakże późniejsze systemy kabalistów będą coraz mocniej eksponować elementy gnostyckie, czego ukoronowaniem będzie znana Miłoszowi kabała Izaaka Lurii ${ }^{26}$. Tak silna obecność elementów gnostyckich nie zmieni jednak rdzenia kabały, która nawet w swym pesymistycznym wariancie reinterpretuje pesymistyczne doświadczenie egzystencji w ten sposób, by pasowało ono do optymistycznego i monistycznego systemu:

Kabalista z największą żarliwością starał się dotrzeć nie tyle do końcowego punktu wszelkiej historii, do mesjanistycznego zakończenia dziejów, ile raczej do ich punktu wyjścia. Innymi słowy, spekulowali bardziej o stworzeniu świata niż jego odkupieniu. Możliwość odkupienia według niego kryła się nie tyle w parciu naprzód przez historię, aby przyśpieszyć nadejście ostatecznego, katastrofalnego przesilenia dziejów, ile raczej w kontemplacyjnym zwróceniu się wstecz, poza historię, ku

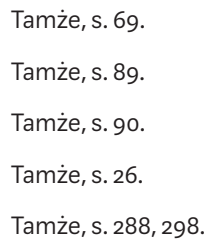


prapoczątkom stworzenia i objawienia, w świetle których można by pojąć prawidłowości rządzące procesem kosmicznym, historycznym i boskim. Kto znał drogę, jaką przeszedł, mógł też mieć nadzieję, że potrafi przejść ją wstecz. ${ }^{27}$

Kabała, zwłaszcza ta, która najbardziej interesowała Miłosza, czyli kabała luriańska, może być więc odbierana jako próba przezwyciężenia dualistycznego i pesymistycznego spojrzenia na rzeczywistość. Agata Bielik-Robson, zauważając "gnostyckie ugięcie"28 kabały Izaaka Lurii, opisuje ją jako szansę na uchwycenie i zachowanie śladów transcendencji w immanencji, tym samym odmawiając jej w pełni gnostyckiego, antykosmicznego i antyimmanentnego charakteru ${ }^{29}$. Tezy Scholema o historycznej relacji kabały i gnostycyzmu znajdują swe odbicie w dziele Czesława Miłosza. Sprowadzając rozważania znów na grunt tej twórczości, można kabałę nazwać lekiem na „manichejskie ukąszenie”. Taka też - zdaniem autora pracy - będzie jej funkcja w tekstach twórcy Dalszych okolic. Jakie konteksty będą więc uruchamiać możliwość kabalistycznego odczytania?

Badacze podkreślają rolę Oskara Miłosza w procesie poznawania przez polskiego poetę kabały. Jak pisze Marek Bernacki, zainteresowanie noblisty takimi myślicielami żydowskimi jak Izaak Luria czy wspomniany już badacz kabały Gerschom Scholem oraz same studia nad kabałą zapoczątkowane zostały przez „wieloletnie studia nad symboliką mistyczno-metafizycznych poematów stryja poety Oskara Władysława de Lubicz Miłosza"30. Heuckelom zwraca również uwagę na to, że to właśnie przy omawianiu kosmologii Oskara Miłosza w Ziemi Ulro Czesław Miłosz przywołuje teorię stworzenia Izaaka Lurii ${ }^{31}$. Poeta nazywa twórczość swego krewnego „medytacją kabalisty" ${ }^{32}$. Nic w tym dziwnego, bowiem, jak zauważają badacze, kosmogonia stworzona przez Oskara Miłosza „wykazuje silne podobieństwa do spekulacji

A. Bielik-Robson Deus otiosus: ślad, widmo, karzeł, w: Deus otiosus. Nowoczesność w perspek-
tywie postsekularnej, red. A. Bielik-Robson, M. Sosnowski, Wydawnictwo Krytyki Politycznej,
Warszawa 2013, s. 33 .

M. Bernacki Problematyka żydowska..., s. 124.

K. Van Heuckelom „Patrzeć w promień od ziemi odbity”..., s. 35.

2 K. Kunisz Tożsamość religijna..., s. 131. 
kabalistycznych"33. Warto więc pamiętać, że odwołania do postaci Oskara Miłosza mogą pozwalać na wykorzystanie kabały przy interpretacji poszczególnych fragmentów dzieł Czesława Miłosza. Tym jednak, co szczególnie interesowało polskiego noblistę, była kabalistyczna kosmogonia, na co zresztą zwracał uwagę sam Miłosz w przywołanym wcześniej cytacie. Jak pisze Krzysztof Kunisz:

Koncepcja ta (hierarchia stworzenia jako człowiek) wyraża pewną analogię między Stwórcą a Stworzeniem, którą przedstawia również koncepcja Człowieka Przedwiecznego, Adama Kadmona, którego opisuje m.in. Izaak Luria. Owa analogia oraz typowy dla kabały hierarchiczny układ bytu pojawia się zarówno u O. W. Miłosza, Blake'a, jak i Swedenborga.U O.W. Miłosza pojawia się jego własna wersja kosmogonii, która jest niezwykle bliska myśli kabalistycznej. Czesław Miłosz opisuje ją w Ziemi Ulro. ${ }^{34}$

By lepiej zrozumieć, jaką rolę odgrywa kabała w twórczości Miłosza, wydaje się zasadne przywołanie koncepcji wypracowanych przez kabałę Izaaka Lurii. Niezbędne jest jednak - z uwagi na charakter pracy i jej objętość - dokonanie pewnych uproszczeń i przywołanie tylko tych elementów tej kosmogonii, które okażą się funkcjonalne dla odczytania sensów zawartych w twórczości Miłosza.

Początek istnienia świata wiąże się dla Lurii z teorią cimcum czyli „wycofania"35. Zgodnie z nią pierwszym etapem stworzenia było wycofanie się Ein Sof - Nieskończonej Istoty - w głąb siebie, w celu zostawienia pustki, czyli przestrzeni dla mającego powstać świata ${ }^{36}$. Świat nie został więc stworzony w myśl koncepcji „coś z niczego”, a wręcz przeciwnie - „nic z wszystkiego”. Następnie Ein $\mathrm{Sof}^{37}$, nieskończoność, powraca do opuszczonego przez siebie miejsca, jednak w formie promienia światła, z którego zostaną stworzone

K. Van Heuckelom „Patrzeć w promień od ziemi odbity”..., s. 34.

K. Kunisz Tożsamość religijna..., s. 132,-133.

M.A. Ouaknin Tajemnice Kabały, przeł. K. i K. Pruscy, Cyklady, Warszawa 2006, s. 190.

Tamże, s. 191.

W pracach badawczych poświęconych kabale i tłumaczonych na język polski pojawią się różne warianty zapisu: Ein Sof, Ejn-Sof, En-Sof. 
światy $^{38}$. Promień ów stał się materią, przybierając postać dziesięciu pojemników, które miały odebrać i przechować boskie światło - nazywa się je sefirot ${ }^{39}$.

Drugi etap stworzenia w kabale luriańskiej nosi nazwę szewira, czyli „rozbicie naczyń" ${ }^{40}$. Naczynia nie wytrzymały i rozpadły się "pod ciśnieniem usiłującej się wydostać zawartości" ${ }^{\text {" }}$. Większosść światła powróciła do swego źródła, jednakże część iskier pozostała „przylepiona” do fragmentów naczyń i upadła w pustkę, dając początek Tamtej Stronie, czyli złu. Fragmenty tych naczyń nazywa się również w kabale łupinami lub skorupami ${ }^{42}$. Rozbicie się naczyń zdezintegrowało porządek ustanowiony przez Boga i w efekcie „wszystko się przemieszało, stało się niedoskonałe i ułomne, jakby potłuczone czy upadłe"43. Wszystko jest więc od tego czasu „na wygnaniu"44. Marc-Alain Ouaknin zwraca uwagę na to, że tak pojmowany upadek i wygnanie nie mają charakteru kary za grzechy, a raczej pewnej misji, której celem jest wyzwolenie boskiego światła z domeny „skorup" ${ }^{\prime 4}$.Ta misja nazywa się tikun, czyli „naprawa”, i musi zostać podjęta przez człowieka ${ }^{46}$. Historia człowieka jest w myśli luriańskiej historią tikun - taki jest też sens Historiii ${ }^{47}$. Jego celem jest „podniesienie iskier" ${ }^{\text {"48 }}$. Co istotne, kabała luriańska nie zakłada istnienia jednego zbawiciela - stał się nim cały lud Izraela ${ }^{49}$.

Powyższe omówienie kluczowych koncepcji nowej kabały można podsumować stwierdzeniem, że jej rewolucyjność na tym właśnie polega, że przywróciła Żydom - i w ogóle ludziom - poczucie godności

\footnotetext{
38 Tamże, s. 193.

39 Tamże.

40 Tamże.

41 Tamże, s. 194.

42 Tamże.

43 Tamże.

44 Tamże.

45 Tamże, s. 195.

46 Tamże.

47 Tamże.

48 Tamże, s. 197.

49 Tamże, s. 201.
} 
i odpowiedzialności. Uświadomiła im, że Historia nie jest żadną fatalnością, nieszczęście nie jest żydowskim przeznaczeniem, a w każdym Żydzie i w całym narodzie tkwi zasób sił do walki o własną wolność i szczęście. ${ }^{50}$

Powyższy komentarz, dotyczący koncepcji Izaaka Lurii, wyjaśnia optymistyczną stronę tej teorii. Historia, choć okrutna i przerażająca, zakończy się w jeden możliwy sposób, właśnie dzięki działaniu człowieka.

Kabalistyczna kosmogonia jest nierozerwalnie związana z metafizyką światła. O roli światła w poezji Czesława Miłosza pisze Heuckelom ${ }^{51}$. Badacz zauważa, że w Świat poema naiwne światło:

nie jest niszczycielską kosmiczną siłą ani symbolem ocalającej interwencji transcendentnego Boga [...] ale jest znakiem więzi między rzeczywistością ziemską a transcendencją. ${ }^{52}$

Rola światła jako pośrednika między rzeczywistością ziemską a transcendencją polega również na możliwości „oczyszczania” i przenoszenia bytów poza granice rzeczywistości materialnej ${ }^{53}$. Przemiana bytów w światło i odsyłanie ich w przestrzeń transcendentną, z której pochodzą, jest utrzymane w duchu myślenia kabalistycznego. O centralnej roli światła w koncepcjach kabalistycznych świadczyć może już choćby tytuł najważniejszego dzieła kabały - Zoharu, czyli Ksieggi Blasku. Marc-Alain Ouaknin uważa, że „kabała obdarza zdolnością przyjmowania światła i nieskończoności"54. Światło to dla kabalistów „pierwszy znak, pierwsze słowo stworzenia, pierwsza i najwyższa rzeczywistość wszechświata, droga ku boskości"55. To dostrzeżone przez Heuckeloma przemienianie bytów w światło i przenoszenie w rzeczywistość transcendentną u Miłosza jest przecież rozumieniem światła w sposób podobny do kabały - jako „drogi ku boskości”. Tym bardziej że metafora ognia jako światła jest w kabale wykorzystywana bardzo często ${ }^{56}$. Podobnie

50

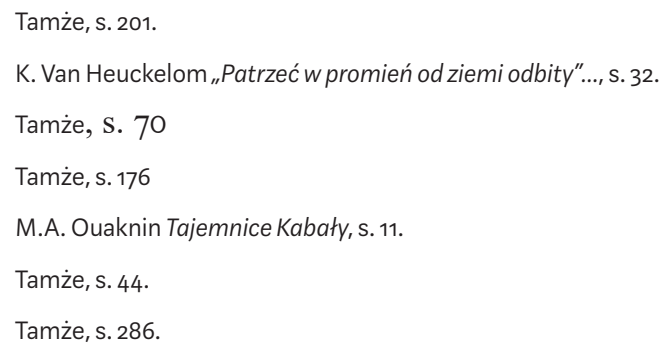


o świetle w twórczości Miłosza z uwzględnieniem jego kabalistycznych konotacji pisze Krzysztof Kunisz:

Lux jest to światło zmysłowe, natomiast lumen jest światłem duchowym, o którym pisali kabaliści, jak również Oskar Władysław Miłosz. Tendencja, o której pisze Heuckelom, nawiązuje do koncepcji zmartwychwstania u Czesława Miłosza, która zasadniczo różni się od koncepcji chrześcijańskiej.Zmartwychwstanie miałoby oznaczać ocalenie wszystkich bytów. ${ }^{57}$

Ocalenie wszystkich bytów, o którym pisze Kunisz, jest nierozerwalnie związane z koncepcjami kabalistów. Zohar, powstały w 1275 roku, nauczał, że wszystkie rzeczy tworzą całość nierozłączną od światła - prawdziwą rzeczywistością jest światło obecne w każdej rzeczy ${ }^{58}$.

W kabale istnieje jeszcze inna drogą, którą możemy łączyć się z Ein-Sof. Są nią litery alfabetu i tekst Tory ${ }^{59}$ - a szerzej język. Świat powstał w języku i poprzez język ${ }^{60}$ - kabała jako ruch mistyczny jest mistyką języka. Boskie światło objawia się w literach alfabetu, a one same pozwalają kabaliście nie tylko interpretować świat, ale nawet stwarzać go na nowo.. Co interesujące, według tradycji kabalistycznej Tora, księga, istniała jeszcze przed powstaniem świata i zawiera w sobie wiedzę o jego dalszych losach ${ }^{61}$. Rolę języka w kabale najlepiej określił Gerschom Scholem:

język w swej najczystszej esencji [...] powiązany jest ściśle z najgłębszą duchową istotą świata, czyli ma wartość mistyczną. Mowa dociera do Boga, gdyż od Boga wyszła. W mowie ludzkiej [...] odzwierciedla się stwórczy język Boga. Całość stworzenia, widziana od strony Boga, jest niczym innym niż tylko wyrazem jego ukrytej istoty, z której głębin wypływają słowa samonazywającego się Boga [...] Koniec końców więc wszystko co żyje, żyje poprzez język Boga. ${ }^{62}$

\footnotetext{
57 K. Kunisz Tożsamość religijna..., S. 140. 
Tym, co powinno zwrócić uwagę badacza Miłosza, jest nie tylko motyw języka - tak ważny dla kabalistów - ale również wiążąca się z nim koncepcja czasu, związana z Torą jako spisanym fundamentem świata. Spróbujmy przyjrzeć się istotności tych ustaleń na przykładzie tomiku Dalsze okolice. Wybór tego tomiku podyktowany jest nie tylko występowaniem w nim tropów odsyłających do kabały, ale również silną obecnością motywów i symboli gnostyckich ${ }^{63}$ - proponowana w niniejszym artykule lektura Miłosza przez kabałę, jest lekturą opierającą się na dialogu z myślą gnostycką. Ich współwystępowanie, nie tylko w obrębie całego tomiku, ale nierzadko wewnątrz pojedynczego utworu, pozwala lepiej i wyraźniej widzieć rolę myśli kabalistycznej w twórczości Miłosza.

Podstawą metodologiczną niniejszej pracy jest, zarysowana przez wielu badaczy - m.in.: przez księdza Jerzego Szymika - a kompleksowo omówiona przez Zofię Zarębiankę, koncepcja wewnętrznej dialogiczności dzieł Czesława Miłosza, wyjaśniająca sposób funkcjonowania rozmaitych, często sprzecznych ze sobą, tradycji, zarówno na poziomie jednego tekstu, jak i całego dorobku polskiego pisarza. Dialogiczność, według badaczy, jawi się jako cecha samej struktury poezji Miłosza ${ }^{64}$, jako wypadkowa wielogłosowości ${ }^{65}$, a w końcu jako wewnątrztekstowy dialog, będący formą polifonii ${ }^{66}$. Zofia Zarębianka zauważa, że pojęcie „wewnętrznej dialogiczności” pozwala odkryć zasadę działania wyobraźni poetyckiej autora ${ }^{67} \mathrm{i}$ proponuje całościowy opis struktury wyobraźni poetyckiej Miłosza, ujęty właśnie w tę formułę ${ }^{68}$. Zarębianka wyjaśnia to zjawisko w sposób następujący:

W odniesieniu do każdego z wymienionych składników ta wewnętrzna dialogiczność przebiega i stosuje się inaczej, zawsze jednak eksponując niedostateczność prezentowanych koncepcji, postaw i wizji, naznaczonych przez świadomość, iż nigdy żadne ludzkie wyobrażenia nie

63 Odniesienia do gnostycyzmu i „gnostyckie doświadczenie egzystencji” można odnaleźć m.in. w wierszach: Pająk, Przybytek, Oset, pokrzywa, Uczestnik, Na plaży, Fotografia, Albo-Albo, A jednak, Rozmowa, Dalsze okolice, Młodość, Wiersz na koniec stulecia, Powrót. Z. Zarębianka Wtajemniczenia (w) Miłosza, Homini, Kraków 2014, s. 267.

Tamże, s. 362.

66 J. Szymik Problem teologicznego wymiaru dzieła literackiego Czesława Miłosza, Księgarnia św. Jacka, Katowice 1996, s. 44.

67 Z. Zarębianka Wtajemniczenia..., s. 354.

68 Tamże, s. 356. 
sięgają ani istoty rzeczy ani, tym bardziej, istoty absolutu i rzeczywistości eschatologicznej, przybliżanych jedynie w kolejnych wyobrażeniach i intuicjach. Nie chodzi tu bynajmniej o aksjologiczny relatywizm, ale o przekonanie, iż człowiek dążąc do prawdy, poznaje ją jedynie po części, w sposób stopniowy i niedoskonały... ${ }^{69}$

Zderzone ze sobą koncepcje, postawy i wizje nie mogą tworzyć syntezy, dlatego że nie taka ma być ich rola. Nie chodzi więc w poezji Miłosza o to, żeby połączyć sprzeczne tradycje religijne i dotrzeć w ten sposób do prawdy. Wydaje się, że choć każdy ze sposobów patrzenia zawiera w sobie część obrazu, to zestawienie go z innymi nie tyle uzupełnia ten obraz, co oświetla jego braki. Właśnie dlatego że jest tak ważna, badaczka opisała dwa „warianty realizacji rzeczonej strategii"70:

a) poprzez celowe aluzje do odległych od siebie obszarów tradycji duchowych, współistniejących niekiedy zgodnie w jednym wierszu" ${ }^{71}$,

b) poprzez możliwość podwójnych deszyfracji w odczytywaniu sensów duchowych wpisanych w tekst ${ }^{72}$.

Ważna staje się relacja między rozmaitymi interpretacjami. Jak pisze Zarębianka:

Przeświadczenie o ukrytej przed oczyma żyjących tajemnicy, o niemożności zgłębienia rozumem zagadki życia i śmierci czyni bohatera Miłosza otwartym na poszukiwania metafizyczne, wyzwalając go zarazem od pokusy doktrynerstwa i od pewności posiadania prawdy. ${ }^{73}$

Koncepcja ta pozwala na zrozumienie wagi interpretowania tekstów Miłosza przez pryzmat danej tradycji religijnej czy filozoficznej, nie w oderwaniu, a w relacji do innych, współwystępujących na jej łamach koncepcji.

Jak już ustaliliśmy, zagadnienie obecności zła w świecie jest kluczowe w myśli zarówno gnostyckiej, jak i kabalistycznej. Miłoszowy podmiot, mówiąc w wierszu Powrót, "Jak to jest możliwe, chyba wymyślone przez

69 Tamże, s, 358.

70 Tamże.

71 Tamże, s. 271-272.

72 Tamże, s. 273.

73 Tamże, s. 253. 
okrutnego demiurga, takie urządzenie świata?"74 zaznajomiony z koncepcją szewiry, dostrzeże okrutne „urządzenie świata”, wzbroni się jednak przed obarczeniem Stwórcy odpowiedzialnością, wiedząc, że był to efekt wypadku, a nie zamierzone działanie. Owe "chyba” w perspektywie kabalistycznej jest zrozumiałe: świat jest „jakby" urządzony przez złego demiurga, jednakże nie jest to bezpośrednią winą Boga. Wina leży w kosmicznej katastrofie, w pęknięciu naczyń, do którego odniesienie odnajdziemy w tym samym tomie, w metaforze „lotnego ognia, nietożsamego z glinianymi garnkami”75.

Luria nauczał, że po szewirze nastąpiło tikun, czyli „naprawa”,której celem jest wyzwolenie światła ze świata materii. Fragment Wiersza na koniec stulecia zakłada, jakoby „żadna moc" nie mogła „obalić przyczyny i skutku”, przekreślając tym samym koncepcję "naprawy”. Jednakże w Dwóch wierszach Miłosz komentuje Wiersz na koniec stulecia, osłabiając jego pesymistyczny wydźwięk ${ }^{76}$. Pytanie o możliwość naprawy pozostaje więc otwarte. Czy w Dalszych okolicach pojawia się możliwość ocalania bytów i - w postaci światła - odsyłania ich do źródła, Ein-sof? Przypomnijmy, że zdaniem Heuckeloma można odnaleźć w tekstach Miłosza taki mechanizm.

Jak wykazuje nasza analiza, w utworach Miłosza, głównie tych z okresu powojennego, motyw ognia włączony został do pewnych wariantów koncepcji apokatastazy rozumianej jako transmutacja światła: ogień przemienia byty w światło i oczyszcza ich esencje, przenosi je w sferę metafizyczna.. ${ }^{77}$

Porównajmy powyższy cytat z fragmentem Rozmowy

Był raz artysta

Wierny i pracowity. Jego pracownia

Ze wszystkim, co namalował, spaliła się,

On sam został rozstrzelany. Nikt o nim nie wie.

Ale obrazy jego trwają. Po drugiej stronie ognia ${ }^{78}$.

Cz. Miłosz Wiersze wszystkie, Znak, Kraków 2011, s. 1029.

Tamże, s. 1001.

Tamże, s. 1013 .

K. Van Heuckelom „Patrzeć w promień od ziemi odbity”..., s. 176.

Cz. Miłosz Wiersze wszystkie, s. 990. 
Myśl, o istnieniu „drugiej strony ognia”, do której przenoszone są - za pośrednictwem światła - byty, jest myślą nie tylko wpisującą się w system Izaaka Luri, ale przede wszystkim, wskazującą na sens procesu tikun. Warto zaznaczyć, że choć metafizyka światła nie odsyła tylko do kabały, ale także do tradycji neoplatonizmu, szkoły z Chartres i Oksfordu, a wreszcie tomizmu, to jednak niniejsza interpretacja - mieszcząca się w modelu wewnętrznej dialogiczności zarysowanym przez Zofię Zarębiankę - nie wyklucza innych odczytań, a raczej akcentuje wynikające z tej wielości tradycji możliwości dialogiczne. Niezwykle interesująca okazuje się ostatnia strofa Dantego czytana w takiej perspektywie:

Nam przyrodzone i stałe pragnienie

Del deiformo regno - bogokształtnej strefy

Krainy czy królestwa. Bo tam jest mój dom.

Nic na to nie poradzę. Modlę się o światło.

$\mathrm{O}$ wnętrze wiecznej perły, aeterna margarita

Już samo wyobrażenie Boga jako „bogokształtnej strefy” ma mocno luriańskie zabarwienie. Scholem wyjaśnia, że En-sof to „nieskończone"79, zawierające w sobie „nieskończoną mnogość odcieni i zróżnicowań” ${ }^{80}$. Pisze on

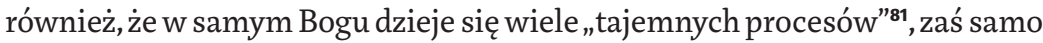
En-sof to „świat emanacji boskich" ${ }^{22}$.Takie wyobrażenie, typowe dla kabały, jest dalekie od wyobrażeń antropomorficznych - Bóg to nie Nieskończony, a Nieskończone. Stąd myślenie o Bogu jako o strefie. Ślad podobnych założeń kosmologicznych pojawia się w Stwarzaniu świata, w którym przestrzeń boska opisywana jest jako „ocean musującej energii" ${ }^{83}$. Wracając jednak do Dantego, należy zauważyć, że - zgodnie z myślą kabalistyczną - tym, co może łączyć człowieka, upadłą światłość, z jej pierwotnym miejscem (domem), czyli „bogokształtną sferą”, jest właśnie światło. Kabalistyczny wymiar tych wyobrażeń stanie się jeszcze bardziej wyraźny, kiedy uświadomimy sobie,

G. Scholem Mistycyzm..., s. 232.

Tamże, s. 233.

81 Tamże.

82 Tamże, s. 240.

83 Cz. Miłosz Wiersze wszystkie, s. 980. 
że „kabała obdarza zdolnością przyjmowania światła i nieskończoności”"84. Najistotniejsza dla kabały jest relacja między światłem a tym, który je przyjmuje ${ }^{85}$. Jeżeli uznamy, że w kontekście odczytań kabalistycznych Miłosz został obdarzony zdolnością przyjmowania światła, to otwieramy w ten sposób dalszą ścieżkę interpretacyjną. Śmierć w symbolice kabalistycznej jest odpowiednikiem szewiry, rozbicia naczyń, „tym co jest zdolne przyjmować, ale nie oddawać" ${ }^{\prime 86}$. Miłosz przyjmujący światło musi potrafić je również oddawać, a więc ocalać (tak jak ocalone zostały obrazy w Rozmowie).

Zwracaliśmy uwagę na rolę języka i słowa w kabale. To w literach zamyka się boskie światło, zaś język pochodzi od Boga. Równie sakralne podejście do słowa zdaje się pojawiać w Filologii:

A wszyscy oni znali te same słowa,

Które są, dalej trwają, choć dawno umarli

Jakby nie z ziemi, nie z nocy, nie z ciała

Przybyły, ale z górnych eterycznych włości. ${ }^{87}$

Koncepcja słów pochodzących z "górnych eterycznych włości" odpowiada kabalistycznemu wyobrażeniu o języku jako drodze komunikacji z Bogiem. Teurdzy poprzez język potrafili przywoływać boskie światło i sprowadzać na ziemię. Dzięki tym kontekstom, wydaje się zrozumiałe stwierdzenie wieńczące pierwszy utwór tomu: „Do tego byłem wezwany: / do pochwalania rzeczy, dlatego że są"88. I choć „pochwalanie rzeczy, dlatego że są”, odruchowo odsyła do metafizyki św. Tomasza, to jednak może mieć ono również wykładnię kabalistyczną. Pochwalanie, mające charakter zamykania w słowa, może być celem przyświecającym całemu tomikowi. Dzieło Miłosza będzie więc dziełem analogicznym do tego, co robił Adam: zbierania i nazywania ${ }^{89}$. Pierwszy człowiek jednak „nie skończył dzieła, wygnany za wcześnie”90. Przeświadczenie, że dzieło to, można zakończyć, znów odsyła czytelnika do myśli

\footnotetext{
84 M.A. Ouaknin Tajemnice Kabały, s. 11.

85 Tamże, s. 116.

86 Tamże, s. 256.

87 Cz. Miłosz Wiersze wszystkie, s. 986.

88 Tamże, s. 977.

89 Tamże, s. 982. 
kabalistów, dla których - w przeciwieństwie do myślenia gnostyków - misja człowieka kiedyś się wypełni, a cała światłość uwięziona w materii zostanie zebrana i odesłana z powrotem do swego boskiego źródła. Miłosz jednak w Dalszych okolicach nie wydaje się pewny, czy takie rozwiązanie jest w ogóle możliwe. Choć w Beinecke Library pisze o przemianie „losu w litery" ${ }^{\prime 1}$, to jednak w komentarzu do Zbierania moreli stwierdza, że „to, co raz tylko było, nie zostaje w słowie" ${ }^{\prime 2}$. W podobnym tonie rezygnacji utrzymana jest Fotografia:

Widzisz, jak się staram,

Dosięgnąć słowami

Tego co najważniejsze

I jak przegrywam. ${ }^{93}$

Słowo - w tym fragmencie - okazuje się nie mieć żadnej relacji z transcendencją. Ocalanie bytów poprzez język wydaje się niemożliwe, a co za tym idzie - również cała misja człowieka okazuje się pozbawiona sensu. Porażka myśli kabały prowadziłaby Miłosza w objęcia gnozy - pesymistyczny wniosek płynący z porażki tikun jedynie pogłębiałby gnostycki pesymizm egzystencjalny. Z drugiej strony, w wierszu Sens poeta zdaje się dochodzić do przeciwnego wniosku:

Gdyby tak było, to jednak zostanie,

Słowo raz obudzone przez nietrwałe usta,

Które biegnie i biegnie, poseł niestrudzony,

Na międzygwiezdne pola, w kołowrót galaktyk

I protestuje, woła, krzyczy. ${ }^{94}$

Trwałość słowa, które nie podlega przemijaniu tak, jak „nietrwałe usta”, które je przebudziło, oraz jego zdolność do przenikania wyższych światów („kołowrót galaktyk”, „międzygwiezdne pola”), a w końcu jego siła sprawcza („wołanie”, ,protestowanie”, ,krzyczenie”) stoją w opozycji do „słów niemogących dosięgnąć tego co najważniejsze”. Wydaje się więc, że jeżeli istnieje

\footnotetext{
91 Tamże, s. 995.

92 Tamże, s. 1025

93 Tamże, s. 1008.

94 Tamże, s. 1036.
} 
jakikolwiek klucz mogący rozwiązać spór o postawę Miłosza względem tikun, to będzie on związany z kabalistyczną koncepcją czasu i mitem Księgi.

Wiele utworów z Dalszych okolic odnosi się do wydarzeń i postaci dających się umieścić na osi czasu. Choć nie jest to zasadą, to jednak do pewnego stopnia, kolejność utworów odpowiada kolejności tego, do czego się odnoszą ${ }^{95}$. Momentem kulminacyjnym takiego ułożenia utworów będzie wiersz Dawno $i$ daleko, w którym - posługując się obrazami wojny i XX-wiecznymi systemami totalitarnymi - Historia objawi swoje najgorsze oblicze. Miłosz kończy Dawno i daleko stwierdzeniem, że „Nie będą znalezione / Pisma z błaganiem o pomoc, mogiły bez krzyża"96, wskazując w ten sposób na tragizm ludzkiej egzystencji i okrucieństwo Historii, skoro tym, co po niej pozostaje, są anonimowe groby $\mathrm{i}$ - nieodnalezione w porę - pisma $\mathrm{z}$ błaganiem o pomoc. Jak w obliczu tak przerażającej wiedzy można utrzymywać wiarę w istnienie boskiego wymiaru i celowości historii?

Kabała odpowiadała na poczucie niesprawiedliwości, które dręczyło Żydów w skutek bolesnych wydarzeń historycznych. Zdaniem Ouaknina i Scholema system Izaaka Lurii ,stanowił odpowiedź na historyczne wstrząsy jego czasów”" dlatego, że „Lurii udało się stworzyć teorię objaśniającą - filozoficzno-mistyczną doktrynę procesu historycznego - która angażuje człowieka, czyniąc go odpowiedzialnym za losy świata i możliwość odkupienia"98. Konsekwencją takiego myślenia o historii było uświadomienie Żydom, że „Historia nie jest żadną fatalnością, nieszczęście nie jest żydowskim przeznaczeniem"99. Nadawanie Historii celu odbywa się również w Dalszych okolicach.

Po Stwarzaniu świata następnym wierszem jest Linnaeus, w którym opisywane jest królestwo natury, oraz Adam, nadający imiona w raju. Tytułowy Linneusz będzie z kolei zapowiadać epokę hrabin, oficerów kawalerii, którą opisuje Wcielony. W kolejnych utworach pojawi się Konstanty Szyrwid, który jest postacią żyjącą wcześniej niż Linneusz, ale jednak w ujęciu całościowym, różnica ta nie jest aż tak znaczna. Cykl WYale rozpocznie się od konstatacji Historii („Bo Historia / Przestaje być zrozumiała"), podkreślając tym samym chronologiczny układ dotychczasowych utworów, oraz dodając do tej kompozycji coś jeszcze - zauważenie, że dopiero od tego momentu, Historia „przestaje być zrozumiała”. Jest to o tyle istotne, że następne utwory wkraczają już w epokę nowoczesności. Przywołane zostaną takie postaci jak Balzac, William Turner, John Constable czy Jean Baptiste Camille Corot (wszystkie żyjące i tworzące na przełomie XVIII ¡XIX w.), a dalej Anna Kamieńska. Cz. Miłosz Wiersze wszystkie, s. 1023. M.A. Ouaknin Tajemnice Kabały, s. 199. Tamże. 
Wiersze przedstawiające historię świata są poprzedzone utworem Adami Ewa, który - choć umiejscowiony jest wcześniej zarówno chronologicznie, jak i w kompozycji tomiku - nadaje sensu wszystkim dalszym utworom.

Wiersz czytany nie przez pryzmat kabały może wydawać się dziwny. Adam i Ewa czytają ,książkę", w której zawierają się losy całego świata. Istotne jest to, że losy te ściśle wiążą się z człowiekiem - począwszy od dzieł literackich (aluzja do Matpy w kapieli Fredry), przez zamki, pałace, miasta i planetarne lotniska:

I nie tylko to czytali Adam i Ewa,

Trzymając książkę na gołych kolanach.

Te zamki! Te pałace! Te spiętrzone miasta!

Planetarne lotniska między pagodami! ${ }^{100}$

Kabała - jak już pisaliśmy - naucza o Torze jako boskiej podstawie świata, księdze istniejącej jeszcze przed jego powstaniem, a która zawiera w sobie jego dalsze losy. Kabalistyczna interpretacja dostarcza klucza do zrozumienia Adama i Ewy - książką, którą czytają pierwsi ludzie, jest właśnie Tora. Na metafizyczny wymiar czytanej księgi wskazuje przejście między pierwszą a drugą częścią utworu. Część pierwsza wiersza sugeruje, że Adam i Ewa czytają Fredrę, jednakże z tej samej księgi Adam i Ewa wyczytują przyszłe losy świata. Wiedza, którą czerpią z księgi, obejmuje nie tylko czasy opisane w reszcie tomu - a więc również traumatyczne doświadczenia wojny. Pojawiające się w tekście planetarne lotniska wykraczają czasowo poza wydarzenia i postaci opisane w Dalszych okolicach. Komiczny charakter pierwszej części utworu nie znosi w żaden sposób wagi części drugiej, a raczej podkreśla jej optymistyczny wydźwięk. Oto posiadając więc pełnię wiedzy, pierwsi ludzie decydują się na wykonanie ruchu, który w konsekwencji rozpocznie całą Historię:

Patrzyli na siebie, uśmiechali się,

Ale niepewnie (będziecie, poznacie)

I ręka Ewy sięgała po jabłko101.

Zwraca uwagę, zwłaszcza w kontekstach dalszych utworów, uśmiech, jaki towarzyszył Adamowi i Ewie, gdy decydowali się na uruchomienie mechanizmów Historii. Miłosz pisze w gnostyckim duchu, że umysł ludzki nie mógłby

100 Cz. Miłosz Wiersze wszystkie, s. 978.

101 Tamże, s. 978. 
pojąć świadomości bólu, który wypełnia wszechświat W Pająku, po wymienianiu okrutnego losu, jaki spotyka owady, podmiot pyta:

Czyż pełna świadomość?

Mogłaby unieść to, co równocześnie

W każdej sekundzie dzieje się na ziemi? ${ }^{102}$

Praprzodkowie w momencie dokonywania wyboru mieli jednak tę świadomość i mimo to podjęli decyzję - z uśmiechem. Historia jest niezrozumiała i straszna, ale tylko z naszej perspektywy.Adami Ewa rzutuje na całość tomiku, nadając grozie Historii i okrucieństwu świata optymistyczną perspektywę kosmiczną. Doświadczenia wojny również zostają w tę perspektywę wpisane, co pozwala oswoić ich koszmarność.

Jeżeli założymy, że Historia jest celowa, a jej zwieńczeniem byłoby ocalenie całej światłości, zamkniętej w świecie materii, oraz że rolą Miłosza jako poety jest ocalanie za pośrednictwem języka, wtedy wiersz Oset, pokrzywa okazuje się utworem niezwykle ważnym. Jest to zresztą utwór, który przede wszystkim zachęca do lektury pesymistycznej i gnostyckiej lub utrzymanej w duchu buddyzmu zen. Do uruchomienia kabalistycznych odczytań zachęca jednak motto autorstwa Oskara Miłosza, od którego polski poeta czerpał inspiracje kabalistyczne. Ciekawa z tego punktu widzenia wydaje się sprzeczność zawarta w kluczowym fragmencie:

Miał mnie okupić dar układania słów

Ale muszę być gotów na ziemię bez-gramatyczną ${ }^{103}$

Sprzeczność wydaje się tylko pozorna - w perspektywie kabalistycznej ziemia bez-gramatyczna nie jest czymś złym. Jest ostatnim i pierwszym etapem losu świata i ludzkości, jest spełnieniem Historii.

Kabalista z największą żarliwością starał się dotrzeć nie tyle do końcowego punktu wszelkiej historii, do mesjanistycznego zakończenia dziejów, ile raczej do ich punktu wyjścia ${ }^{104}$

\footnotetext{
102 Tamże, s. 299.

103 Tamże.

104 G. Scholem Mistycyzm..., s. 272.
} 
Według Scholema punktem wyjścia jest Tora, która na początku (przed kosmiczną katastrofą) była „chaotycznym zbiorem niepowiązanych ze sobą liter"105, „wszystkie litery Tory były zmieszane ze sobą"106. Ouaknin, pisząc o Torze Boga, czyli Torze Pierwotnej, opisuje ją jako potok pisma płynący litera za literą, w którym nie ma „żadnej interpunkcji” i „żadnych cięć”107. Ziemia bez-gramatyczna to, być może, Tora Pierwotna, punkt, do którego dąży Historia.

Kabała, rozumiana jako próba pogodzenia wpływów gnostyckich i mistyki merkawy, jest równocześnie próbą przekroczenia dualizmu i pesymizmu manichejskich koncepcji. Jej reinterpretacja mitu upadku i stworzenia i optymistyczne spojrzenie na rolę Historii mogą wydawać się niezwykle kuszące dla kogoś takiego jak Czesław Miłosz - poety odczuwającego gnostyckie doświadczenie egzystencji. Tym bardziej kuszące, że sama kabała również z podobnego doświadczenia wyrasta. Zaproponowany tryb lektury nie jest ani całościową interpretacją tomiku, ani nawet trybem konkurencyjnym wobec innych sposobów czytania. Ujawnia on raczej inny, wpisany w koncepcję wewnętrznej dialogiczności, sposób czytania, w którym poszczególne interpretacje - w tym wypadku gnostycka i kabalistyczna - nie konkurują ze sobą, a raczej oświetlają się wzajemnie. Odczytania kabalistyczne nabierają sensu, gdy dokonuje się ich w relacji do gnostyckich. Co więcej, silnie obecne w Dalszych okolicach odniesienia do buddyzmu zen staną w kontrze do obu wymienionych perspektyw - ale to już materiał na dalsze badania.

105 G. Scholem Kabała i jej..., s. 112.

106 Tamże.

107 M.A. Ouaknin Tajemnice Kabały, s. 317. 


\section{Abstract}

\section{Krzysztof Brenskott}

JAGIELLONIAN UNIVERSITY (CRACOW)

Taming History: The Kabbalah in Czesław Miłosz's Poetry Collection Provinces [Dalsze okolice]

Brenskott discusses Kabbalistic motifs and their relationship with Gnosticism in Czesław Miłosz's work. His theoretical investigation is complemented by an exemplary analysis of the poems in Miłosz's Provinces [Dalsze okolice]. The secondary literature on the subject is slim in comparison with the works dedicated to other religious traditions in Miłosz's work. If is mentioned at all, Kabbalism usually appears in the context of Miłosz's relationship to Judaism and the Gnostic tradition. Gnosticism, however, is key if we hope to understand the role of the Kabbalah in Miłosz's work, since Gnosticism and the Kabbalah are closely intertwined.

\section{Keywords}

Kabbalah, Gnosticism, Czesław Miłosz, Provinces, Isaak Luria 